\title{
ANALISIS SIKAP BELA NEGARA SISWA PADA PEMBELAJARAN PPKn DI SMP NEGERI 5 KETUNGAU HULU
}

\author{
Juri \\ STKIP Persada Khatulistiwa Sintang, Pendidikan Pancasila dan Kewarganegaraan,Sintang \\ Email: jurisaputra85@gmail.com
}

\begin{abstract}
This research is based on the assumption that defending students in border regions tends to be less.This is because they interact with citizens from neighboring countries every day.However, in reality the sense of nationality of these students is very thick, although to meet the needs of everyday life they rely more on goods from abroad.This reality is a necessity, not a desire. That is, if they have to go down to the district center, the distance takes quite a long time.The methodology used in this study is descriptive qualitative. Researchers only present the results of the research in narrative form without manipulating data from the field.The results of the study show: (1) the state's defense attitude is basically good. This is proven, every Monday they always carry out the flag ceremony.In addition, students are active in extracurricular activities, in the form of scouts, volleyball, foot ball and martial arts.The companion in the scout and martial arts (karate) activities was the Army which happened to be at the time serving as a border guard.(2) the implementation of these activities is routine one time a week.(3) every Monday students take part in the flag ceremony, every Tuesday karate training, every Wednesday volleyball training, every Thursday foot ball training, and every Friday scout training.
\end{abstract}

Keywords: Analysis, Defending Attitudes of Student Countries, PPKn Subjects 


\begin{abstract}
Abstrak
Penelitian ini bertolak dari asumsi bahwa sikap bela negara siswa di daerah perbatasan cenderung kurang. Ini dikarenakan mereka setiap hari berinteraksi dengan warga dari negara tetangga. Lokasi penelitian berjarak sekitar 4 jam berjalan dari tapal batas. Namun, kenyataannya rasa kebangsaan siswa tersebut amat kental, walaupun untuk memenuhi kebutuhan hidup sehari-hari mereka lebih banyak mengandalkan barang-barang dari luar negeri.Kenyataan tersebut merupakan sebuah kebutuhan, bukan keinginan. Artinya, apabila mereka harus turun ke pusat kabupaten, jarak tempuh memakan waktu yang cukup lama. Metodologi yang digunakan dalam penelitian ini adalah kualitatif deskriptif. Peneliti hanya memaparkan hasil penelitian dalam bentuk narasi tanpa memanipulasi data dari lapangan. Hasil penelitian menujukkan: (1) sikap bela negara siswa pada dasarnya baik. Ini terbukti, setiap hari senin mereka selalu melaksanakan upacara bendera. Disamping itu, siswa aktif dalam kegiatan ektrakurikuler, berupa pramuka, voly, bola kaki dan bela diri. Yang menjadi pendamping dalam kegiatan pramuka dan bela diri (karate) adalah TNI Angkatan Darat yang kebetulan pada saat itu bertugas sebagai penjaga perbatasan.(2) pelaksanaan kegiatan tersebut rutin yakni satu kali dalam seminggu. (3) setiap hari senin siswa mengikuti upacara bendera, setiap hari selasa latihan karate, setiap hari rabu latihan voly, setiap kamis latihan bola kaki, dan setiap jum'at latihan pramuka.
\end{abstract}

Kata Kunci: Analisis, Sikap Bela Negara Siswa, Mata Pelajaran PPKn. 


\section{A. Pendahuluan}

Pendidikan adalah memberi pertolongan secara sadar dan sengaja kepada seorang anak (belum dewasa) dalam pertumbuhannya menuju kearah kedewasaan dalam arti dapat berdiri sendiri dan bertanggung jawab susila atas segala tindakannya menurut pilihannya sendiri, Pidarta, (2007:10). Sementara itu dalam Undang-Undang RI No. 20/2003 pasal 1 ayat (1) didefinisikan bahwa pendidikan adalah sebagai usaha sadar dan terencana untuk mewujudkan suasana belajar dan proses pembelajaran sehingga peserta didik secara aktif mengembangkan potensi dirinya untuk memiliki kekuatan spiritual keagamaan, pengendalian diri, kepribadian, kecerdasan, akhlak mulia, serta keterampilan yang diperlukan masyarakat, bangsa dan negara.

Sejalan dengan perkembangan ilmu pengetahuan dan teknologi dewasa ini menuntut manusia untuk lebih kreatif dalam mengembangkan daya intelektual maupun sosial guna menunjang pembangunan bangsa. Tolok ukur kemajuan dari berbagai dimensi ilmu pengetahuan tentunya tidak lahir secara instan, melainkan melalui sebuah perjuangan yang tak kenal lelah dari para ilmuan yang haus akan ilmu pengetahuan dalam menyempurnakan berbagai teori yang dianggap sudah tidak sesuai lagi dengan perkembangan zaman. Oleh karena itu, dewasa ini pemerintah Indonesia sudah mulai menggalakkan sistem pengajaran yang komprehensif dan berkesinambungan mulai dari tingkat Taman Kanak-Kanak sampai dengan Perguruan Tinggi. Hal ini juga sejalan dengan amanah UUD NRI 1945 khususnya pada pasal 31 ayat (1) dan (2) (sebelum diamandemen). Di dalam ayat (1) dikatakan "Tiap-tiap warga negara berhak mendapat pengajaran". Kemudian pada ayat (2) dikatakatan "Pemerintah mengusahakan dan menyelenggarakan satu sistem pengajaran nasional, yang di atur dengan Undang-Undang. Dengan demikian pendidikan mempunyai peran yang sangat fundamental demi kemajuan sebuah negara dalam menghasilkan out put sumber daya manusia yang berkualitas sesuai dengan kebutuhan masyarakat dan mampu menjawab tantangan era globalisai pada saat ini dan masa yang akan datang. 
Dewasa ini pembelaan terhadap negara tidak lagi dilakukan dengan mengangkat senjata seperti pada saat penjajahan dahulu, melainkan sudah menempuh jalur yang berbeda karena kita berjuang bukan lagi dalam rangka merebut kemerdekaan tetapi sudah mengisi kemerdekaan. Oleh karena itu, salah satu cara yang dapat ditempuh untuk berjuang dalam membela negara pada masa sekarang adalah dengan menempuh pendidikan yang setinggitingginya karena hanya melalui pendidikan seseorang bisa menatap masa depannya yang lebih baik. Bela negara adalah suatu tekad dan keinginan yang dilakukan oleh setiap warga negara untuk mempertahankan eksistensi negara dari berbagai ancaman yang datang dari luar maupun dari dalam sehingga dengan demikian keutuhan negara bisa terjaga dengan baik. Kesadaran bela negara juga bisa dilakukan sesuai dengan profesi yang dimiliki oleh seseorang, yang mengandung arti: (1) kecintaan pada tanah air, (2) kesadaran berbangsa dan bernegara, (3) keyakinan akan Pancasila dan UUD NRI 1945, (4) kerelaan berkorban bagi bangsa dan negara, (5) sikap perilaku awal bela negara, Darmadi (2010:1-2).

Dalam penelitian yang peneliti laksanakan di SMP 5 Ketungau Hulu, peneliti tertarik dengan permasalahan tentang bela negara karena berdasarkan informasi yang peneliti peroleh pada saat melakukan pra penelitian sikap bela negara siswa di SMP tersebut masih terbilang kurang. Faktor-faktor yang menyebabkan sikap bela negara siswa masih kurang seperti itu yang berusaha peneliti ungkapkan dalam karya ilmiah ini. Sehingga yang menjadi pertanyaan sekarang adalah faktor-faktor apa sajakah yang menyebabkan siakp bela negara siswa di SMP 5 Ketungau Hulu masih kurang? Padahal kita ketahui bersama bangsa Indonesia sudah lebih dari setengah abad merdeka, tapi kenapa sampai sekarang daerah perbatasan khususnya dalam hal pendidikan masih sangat terbelakang. Sedangkan daerah perbatasan merupakan serambi depan bagi suatu negara yang menjadi cerminan maju atau tidaknya negara tersebut. Sementara itu dalam Batang Tubuh UUD NRI 1945 khususnya pada pasal 31 (sebelum diamandemen) sudah sangat jelas dikatakan bahwa "Tiap-tiap warga negara berhak mendapatkan 
pengajaran". Akan tetapi kalau hal tersebut kita kaji ulang masih sangat jauh dari harapan yang dinginkan karena sampai dengan saat ini masih banyak anak usia sekolah yang tidak bisa bersekolah karena berbagai kendala.

Dengan merujuk pada fenomena di atas, maka pemerintah melalui Dinas Pendidikan Nasional menyelenggarakan atau mengusahakan pengajaran mulai dari tingkat Taman Kanak-Kanak sampai dengan Perguruan Tinggi baik dalam bentuk formal maupun informal dimana kesemuanya itu adalah demi mencerdaskan kehidupan bangsa sesuai dengan amanah Pembukaan UUD NRI 1945 khususnya pada alenia ke-4.

Hal lainnya yang membuat peneliti tertarik untuk melakukan penelitian di SMP Negeri 5 tersebut adalah karena letak sekolahnya sudah tidak jauh lagi dengan tapal batas Indonesia-Malaysia. Dan pada saat ini pemerintah mulai fokus untuk membangun daerah perbatasan, bahkan pemerintah pusat dalam hal ini Presiden Susilo Bambang Yudoyono yang diamanatkan kepada menteri dalam dan luar negeri serta menteri pembangunan daerah tertinggal sudah membentuk
Badan Pengelolaan Daerah Perbatasan. Dan pada saat ini juga isu tentang daerah perbatasan menjadi ramai diperbincangkan di media massa. Salah satu contohnya adalah dengan digelarnya Rapat Koordinasi Percepatan Pembanguan Daerah Perbatasan (P2DP) yang berlangsung di Kabupaten Sintang Kalimantan Barat pada hari Jum'at, 8 Juni 2012, Kapus Post, (2012:16). Dalam rapat tersebut dihadiri sekitar 43 orang dari berbagai kementerian dan lembaga yang datang ke Sintang dengan menghasilkan 9 (sembilan) rumusan penting yang menyangkut daerah perbatasan, salah satunya adalah "Mendorong dan meningkatkan kualitas sumber daya manusia melalui program penguatan pendidikan dan kesehatan masyarakat".

\section{B. Metode}

Agar hasil penelitian ini lebih terarah dalam memecahkan masalah yang diangkat dalam penelitian ini, maka perlu di pilih metode dan bentuk penelitian yang sesuai dengan masalah dan tujuan penelitian tersebut. Untuk itu peneliti akan menguraikan beberapa istilah di bawah ini: 
Nawawi, (2007:65 \& 67) mengatakan bahwa metode penelitian adalah cara yang dipergunakan untuk mencapai tujuan. Lebih lanjut dikatakan bahwa metode deskriptif adalah prosedur pemecahan masalah yang diselidiki dengan menggambarkan atau melukiskan keadaan subyek atau obyek penelitian (seseorang, lembaga, masyarakat dan sebagainya) pada saat sekarang berdasarkan fakta yang tampak atau sebagaimana mestinya. Sementara menurut Sugiyono, (2110:15) mengatakan metode penelitian kualitatif adalah metode penelitian yang berlandaskan pada filsafat postpositivisme, digunakan untuk meneliti pada kondisi obyek yang alamiah, (sebagai lawannya adalah eksprimen) dimana peneliti adalalah sebagai instrument kunci (key intrument), pengambilan sampel sumber data dilakukan secara purposive dan snowball, teknik pengumpulan dengan triangulasi (gabungan), analisis data bersifat induktif atau kualitatif, dan hasil penelitian kualitatif lebih menekankan makna dari pada generalisasi.

Berdasarkan pada pendapat diatas, maka metode yang digunakan dalam penelitian ini adalah deskriptif. Penelitian kualitatif deskriptif bertujuan untuk menggambarkan secara sistematik dan akurat fakta serta karakteristik mengenai populasi pada bidang tertentu. Adapun fakta-fakta yang dideskripsikan dalam penelitianini berkaitan dengansikapbela negara siswa, faktor pendukung dan penghambat sikap bela negara siswa, dan upaya yang dilakukan guru dalam mengatasi faktor penghambat tersebut.

Adapun bentuk penelitian yang digunakan tentunya akan menentukan arah penelitian yang akan dilaksanakan. Berkenaan dengan hal tersebut, maka bentuk penelitian ini masuk dalam golongan penelitian deskriptif. Nawawi, (2007:68) mengatakan bahwa bentuk penelitian yang termasuk kedalam penelitian deskriptif adalah penelitian survai(survey Studies), Studi hubungan (Interrlationship Studies), Studi perkembangan (Development Studies). Selanjutnya dikatakan bahwa ciri-ciri metode deskriptif yaitu: memusatkan masalah yang ada pada saat penelitian dilakukan atau masalah yang bersifat aktual, menggambarkan fakta tentang masalah yang diselidiki sebagaimana adanya, 
diiringi dengan interpretasi rasional yang adequate.Sementara itu, menurut Sukmadinata (2010:72), penelitian deskriptif adalah suatu bentuk penelitian yang paling dasar dan ditujukan untuk mendeskripsikan atau menggambarkan fenomena-fenomena yang ada, baik fenomena yang bersifat alamiah ataupun rekayasa manusia.

Apabila ditinjau dari permasalahan yang diangkat dalam penelitian ini maka, bentuk penelitian yang digunakan adalahpenelitian survei. Untuk itu di bawah ini akan peneliti uraikan secara singkat tentang survai:

\section{a. Pengertian Penelitian Survai}

Bentuk penelitian survai adalah penelitian yang mengambil sampel dari satu populasi dan menggunakan kuesioner sebagai alat pengumpulan data yang pokok, Singarimbun \& Effendi, (1995:3). Penelitian survai juga bisa diartikan sebagai penelitian yang digunakan untuk mengumpulkan data atau informasi tentang populasi yang besar dengan menggunakan sampel yang relatif kecil, Sukmadinata, (2010:82). Atau dengan kata lain penelitian survai adalah untuk mengamati bahkan menyelediki segala sesuatu yang telah terjadi pada masa lalu.

\section{b. Ciri-ciri Penelitian Survei}

Ikhsanudin, $\quad \operatorname{Dkk}(2012: 30)$ mengatakan ada beberapa ciri khas penelitian survei, diantaranya: (a) Logis, (b) Deterministik yaitu penelitian survai harus menentukan sistem atau kerangka berpikir terlebih dahulu dan membangun hipotesis untuk dibuktikan, (c) Umum/general yaitu tidak hanya dimaksudkan untuk menjelaskan sampel saja melainkan untuk digeneralisasikan secara lebih luas sampai pada cakupan populasinya, (d) Hemat, yaitu untuk meneliti pada populasi yang besar, peneliti dapat menggunakan sampel, untuk menganalisis data, peneliti dapat menggunakan komputer dan untuk meneliti fenomena yang rumit dalam kehidupan yang mengandung banyak unsur, peneliti dapat menggunakan kerangka berpikir yang dimodelkan dari hubungan-hubungan antar variabel, (e) Spesifik yaitu sebelum mengambil data, seorang peneliti harus menyusun definisi operasional terhadap variabel yang akan diteliti.

c. Langkah-langkah Penelitian Survei

Dalam hal ini penelitian survai mempunyai beberapa prosedur atau 
langkah yang mesti dilewati menurut Millan \& Schumacher (2001) dalam Sukmadinata (2010:88) :

1) Merumuskan tujuan umum dan tujuan khusus

2) Memilih sumber dan populasi target

3) Pemilihan teknik dan pengembangan instrumen pengumpulan data

Sementaraitu, menurut Singarimbun dan Effendi 1995:27), langkah-langkah penelitian survai adalah: (1) teori, (2) hipotesa, (3) observasi, (4) generalisasi empiris, (5) penerimaan/penolakan hipotesa.

\section{d. Unsur-unsur Penelitian Survei}

Adapun unsur-unsur dari penelitian survai menurut Masri Singarimbun dan Sofian Effendi 1995:30-46) adalah konsep, proposisi, teori, variabel, hipotesa, definisi operasional.

e. $\quad$ Manfaat Penelitian Survei

Menurut Sukmadinata, (2010:8283), manfaat dari penelitian survai, yaitu:

1) Untuk memperoleh gambaran umum tentang karakteristik populasi, seperti komposisi masyarakat berdasarkan pada usia, jenis kelamin, pendidikan, pekerjaan, agama, suku dll

2) Untuk mengumpulkan data berkenaan dengan sikap, nilai, kepercayaan, pendapat, pendirian, keinginan, cita-cita, perilaku, kebiasaan

3) Untuk mengumpulkan data tentang guru, misalnya data tentang latar belakang sosialekonomi, pendidikan dan pengalaman, kepedulian mereka tentang masalah pendidikan, kinerja mereka dalam pelaksanaan mengajar.

\section{f. Tujuan Penelitian Survei}

Selanjutnya Sukmadinata, (2010:82-83) berpendapat bahwa, tujuan dari penelitian survai, yaitu:

1) Untuk mendapatkan data yang berasal dari populasi yang besar dengan mengambil sampel yang relevan

2) Untuk mendeskripsikan keadaan yang ada dilapangan selama dan setelah proses penelitian dilakukan

g. Kelebihan dan Kekurangan Penelitian Survai 
Ada beberapa bentuk kelebihan dan kekurangan dari penelitian survai, diantaranya, Ikhsanudin, Dkk (2012):

1) Kelebihan Penelitian Survei

a) Murah dan cepat, sehingga informasi yang dibutuhkan dapat dihasilkan secara akurat dan tepat waktu

b) Bentuk kuesioner yang digunakan relatif sederhana, sehingga tidak memerlukan pelatihan secara khusus

c) Dapat digunakan untuk mengumpulkan informasi secara sistematis mengenai insedensi penyakit, investigasi kualitas hidup manusia dan perilaku masyarakat

d) Tidak terlalu menyita upaya pihak peneliti, sehingga memungkinkan mendapat informasi (data) dari subyek dalam jumlah yang banyak

2) Kelemahan Penelitian Survei

a) Sulit mengkondisikan subyek atau responden untuk mengisi dan mengembalikan survai atau kuesioner yang telah disebarkan, bisa juga terjadi kerusakan terhadap kuesioner, dan lain sebagainya.

b) Dapat digunakan untuk menjangkau populasi yang besar dan luas tetapi tidak dapat digunakan untuk mendalami kasus-kasus atau masalah-masalahnya secara lebih dalam.

\section{h. Hakekat Penelitian Survei}

Penelitian survei pada dasarnya bisa masuk ke dalam metode penelitian kualitatif dan metode penelitian kuantitaif. Seorang peneliti yang hendak menggunakan bentuk penelitian survai tentunya harus berpijak pada dua instrument ilmu pengetahuan yaitu: logika atau rasionalitas dan observasi atas fakta-fakta empiris. Suatu teori sosial membantu peneliti menentukan hubungan logis untuk menerangkan suatu fenomena sosial, sedangkan penelitian adalah cara untuk melihat apakah hubungan tersebut terjadi dalam kehidupan sosial yang nyata.

Dua unsur ilmu pengetahuan (dalam ilmu sosial) yang tidak dapat dipisahkan, yaitu: integritas logika dan verifikasi empiris. Dalam ilmu pengetahuan atau dalam penelitian jika hasilnya hanya mengandalkan pada 
logika semata, maka kesimpulan dari penelitian tersebut tidak bisa $100 \%$ dibenarkan karena kemungkinan tidak dapat bertahan dalam pengujian empirisnya. Sebaliknya, kumpulan fakta empiris semata tidak secara langsung menumbuhkan atau memberikan pemahaman kita tentang suatu fenomena sosial tertentu sehingga belum ada manfaatnya bagi ilmu pengetahuan. Penelitian survai dimulai dengan munculnya minat dari peneliti terhadap suatu fenomena sosial tertentu karena berawal dari minat itu, maka membuat peneliti semakin bersemangat untuk memecahkan masalah yang diangkat dalam penelitian tersebut, Singarimbun \& Effendi (1998:17-25).

\section{i. $\quad$ Ruang Lingkup Penelitian Survei}

Penelitian survei ini kebanyakan digunakan dalam lingkungan yang berkenaan dengan fenomena sosial dimana konsep yang diteliti adalah bersifat abstrak. Melalui survei, biasanya populasinya sangat besar, oleh karena itu peneliti perlu menentukan sampel yang dianggap bisa mewakili dari populasi tersebut. Dari langkah menentukan sampel itu diperoleh sejumlah informasi (data) yang relevan buat penelitiannya.
Hal lain yang menjadi kajian dari penelitian survei ini adalah berkaitan dengan konsep, proporsi, teori, variable, hipotesa dan definisi operasional, dimana semua hal ini harus dilakukan oleh peneliti dalam proses penelitiannya terutama berkaitan dengan fenomena sosial karena masalah sosial itu adalah sangat komplek, oleh karena itu tidak cukup kalau hanya dikaji secara empiris semata melainkan harus diungkapkan dengan teori sehingga hasil akhir/kesimpulan dari penelitian bisa bermanfaat bagi kemajuan ilmu pengetahuan, Singarimbun \& Effendi (1998:25-30).

\section{Pembahasan Dan Hasil}

1. Pembahasan

a. Sikap bela negara siswa pada pembelajaran PKn SMP negeri 5 Ketungau Hulu

Pada dasarnya sikap bela negara siswa sudah lumayan baik. Hal ini bisa dibuktikan dengan data bahwa setiap hari senin siswa beserta dewan guru melaksanakan upacara bendera, hari rabu ada kegiatan Bakti Sosial di lingkungan sekolah dan masyarakat, pada hari jum'at siswa melaksanakan kegiatan pramukayang dilatih oleh TNI 
Angkatan Darat yang bertugas di perbatasan serta ada juga kegiatan olahraga atau mata pelajaran penjaskes.

Saat guru menyampaikan pelajaran siswa mendengarkan dengan serius, sikap mereka juga baik serta kerapian dan kebersihan kelas terjaga dengan baik. Keberadaan sekolah ini yang dipelosok menyebabkan siswa belum terkontaminasi oleh pergauluan bebas serta pengaruh negatif lainnya, sikap siswa terhadap guru juga sudah baik. Hal ini bisa dibuktikan ketika siswa masuk ke kantor, mereka (siswa) selalu memberikan salam (mengetuk pintu), ketika lewat di depan guru mereka selalu menyapa dengan ramahnya dan membungkukan badan. Pada saat upacara dan kegiatan pramuka siswa menunjukkan sikap yang baik. Siswa bisa bekerjasama dalam kelompok, menghargai pendapat teman dan dalam kelas tersedia gambar para pahlawan, selanjutnya masalah agama juga mendapat pembinaan yang baik sesuai dengan agama yang dianut oleh setiap siswa.

b. Faktor yang mendukung dan menghambat sikap bela negara siswa pada pembelajaran PKn di SMP negeri 5 Ketungau Hulu.
Adapun faktor pendukung sikap bela negara siswa diantaranya: Siswa pernah ikut perkemahan perbatasan yang diselenggarakan oleh pihak kepolisian dari Kabupaten Sintang, setiap hari senin siswa beserta dewan guru selalu melaksanakan upacara bendera, setiap hari jum'at siswa mengikuti kegiatan pramuka yang biasanya dibina oleh pihak TNI yang bertugas di perbatasan, hampir di setiap kelas ada gambar pahlawan perjuangan kemerdekaan, gambar presiden serta wakilnya dan gambar (teks) Pancasila. Hal lain yang menjadi pendukung adalah walaupun keberadaan SMP ini di perbatasan bahkan jalan kakisekalipun bisa di tempuh kurang lebih 3 jam ke Malaysia, tetapi siswa tetap memilih atau mencintai Indonesia dengan segala keterbatasan yang ada.

Namun walaupun demikian hal tersebut harus tetap menjadi perhatian dari pihak pemerintah jangan sampai terus mengabaikan pembangunan di wilayah perbatasan dan kalau dari segi keamanan bisa dikatakan tidak terlalu dibutuhkan sebab kalau peneliti melihat selama melakukan penelitian daerah tersebut sudah aman terkendali, oleh karena itu dalam hal ini peneliti dapat 
menyimpulkan bahwa yang benar-benar diharapkan atau dibutuhkan oleh siswa dan masyarakat disana adalah hanya pembangunan semata yang merata di segala bidang kehidupan.

Faktor pendukung lainnya adalah sudah banyak warga yang punya TV, radio, adanya perpustakaan walaupun buku-bukunya masih sangat minim, disiplin yang sudah berjalan dengan baik, dan gedung sekolah yang sudah lumayan bagus.

Selama proses penelitian, peneliti menemukanbeberapa hal yang menjadi penghambat sikap bela negara siswa, diantaranya:Siswa kadang kala malas belajar sehingga pada kenikan kelas ada siswa yang nilainya tidak mencapai KKM, yakni 70,siswa banyak yang tidak punya buku pegangan, sarana olahraga masih minim, siswa banyak yang belum berani bertanya pada guru.

Hal lainnya yang menjadi penghambat adalah banyaknya keluhan dari guru ketika harus berurusan ke Sintang apalagi kalau sudah musim hujan tiba. Bahkan pengalaman dari peneliti sendiri ketika pergi dari Sintang menuju ke tempat penelitian yaitu di Desa Jasa atau tempat SMP Negeri 5
Ketungau Hulu Berada, harus rela menginap 3 malam di jalan karena mobil yang ditumpangi amblas disebabkan jalan yang menghubungkan Kota Sintang dengan Kecamatan Ketungau Hulu (Senaning) rusak parah. Sangat ironis memang, apalagi kalau kita mengingat bahwa pada saat ini sudah dibentuk tim khusus yang mengelola daerah perbatasan, namun tim ini belum ada hasil yang bisa dinikmati oleh pihak sekolah (siswa). Para siswa juga lebih banyak yang paham tentang Malaysia daripada Indonesia bahkan mayoritas siswa belum pernah turun ke Sintang. Kalau ke Malaysia bisa berjalan kaki 3 sampai 3,5 jam. Sementara kalau pergi ke Sintang harus rela menempuh perjalanan 5 s/d 7 jam pada saat musim kemarau. Tapi kalau musim hujan bisa menempuh perjalanan sampai 10 jam serta kalau dari segi biaya Rp 300.000 s/d Rp 350.000 belum termasuk biaya makan.

Badan pengelolaan daerah perbatasan yang dibentuk pemerintah pusat dan daerah, sampai saat ini belum ada hasil yang bisa dinikmati oleh masyarakat perbatasan. Dari segi ekonomi, masyarakat (para orang tua 
murid) dan siswa serta guru-guru juga lebih mengunggulkan produk buatan negara tetangga dan memang tidak sedikit barang buatan Malaysia yang beredar di sana, mulai dari makanan, minuman, barang-barang elektronik dan bahkan mesin sekalipun. Kendala lainnya adalah masih banyak para orang tua yang enggan untuk menyekolahkan anaknya walaupun guruselalu menyarankan supaya setiap orang tua harus menyekolahkan anaknya supaya bisa bersaing dalam menatap masa depan terutama pada era globalisasi seperti sekarang ini dan pada masa yang akan datang.

\section{c. Upaya yang dilakukan guru dalam mengatasi faktor penghambat sikap bela negara siswa pada pembelajaran PKn di SMP Negeri} 5 Ketungau Hulu

Adapun upaya yang telah dilakukan oleh guru dalam rangka mengatasi faktor penghambat sikap bela negara siswa, diantaranya adalah: setiap hari senin siswa beserta dewan guru melaksanakan upacara bendera, setiap hari jum'at siswa ada kegiatan pramuka, guru menerapkan disiplin sekolah (ketika siswa bolos tanpa alasan maka pihak sekolah memberikan teguran pada siswa dengan memanggilnya ke kantor), setiap ada mata pelajaran kesenian siswa diwajibkan untuk menyanyikan lagu kebangsaan, guru juga memberikan kebebasan pada setiap siswa untuk mengembangkan bakatnya terutama dalam bidang olahragadan dalam mata pelajaran yang paling mereka sukai.

Disisi lain hal yang dilakukan oleh guru diantaranya, bahwakedepan akan di bangun laboratorium dan asrama untuk siswa karena saat ini siswa ada yang tinggal di sekolah karena memang asrama belum tersedia.

Selanjutnya guru sering melakukan sosialisasi pada setiap orang tua murid supaya menyekolahkan anaknya karena memang pendidikan itu sangat penting bagi perkembangan dunia sekarang dan pada masa yang akan datang, guru juga berusaha selalu menjaga hubungan baik dengan siswa, dengan orang tua siswa serta dengan sesama guru, siswa dilarang masuk kelas dan kantor menggunakan sepatu.

Disisi lain upaya yang dilakukan guru adalah memberikan hukuman pada siswa yang melanggar aturan sekolah (misalnya, tidak masuk sekolah 1 hari, siswa tersebut akan dipanggil ke kantor, 
tidak masuk 3 hari berturut-turut, siswa tersebut akan di beri peringatan secara tertulis, tidak masuk 1 minggu, maka orang tua dari siswa tersebut akan di panggil ke sekolah).

\section{Hasil}

\section{a. Sikap bela negara siswa pada pembelajaran PKndi SMP Negeri}

\section{Ketungau Hulu.}

Dari hasil proses penelitian yang telah dilakukan, ditemukan bahwa bentuk bela negara siswa, diantaranya:Setiap hari senin siswa beserta dewan guru selalu mengadakan upacara bendera, siswa pernah dilibatkan dalam perkemahan perbatasan yang dilakukan oleh pihak kepolisian Kabupaten Sintang, setiap hari rabu mengadakan bakti sosial di sekolah dan masyarakat, hari jum'at mengadakan kegiatan pramuka.

Disamping itu juga guru sebagai tenaga pendidik selalu menjaga hubungan baik dengan setiap siswa, dengan orang tua, serta dengan sesama guru. Selanjutnya, guru menerapkan disiplin terhadap semua siswa, baik terkait dengan jam masuk kelas maupun dengan masalah pakaian dan waktu belajar di rumah.
Hal tersebut bertujuan untuk meningkatkan sikap bela negara siswa karena maju atau mundur sebuah negara, terletak pada generasi penerus pada masa yang akan datang, oleh karenanya generasi mendatang harus dipersiapkan sedini mungkin, apalagi letak SMP Negeri 5 ini berada di beranda depan garis perbatasan, dimana warganya hampir setiap hari masuk ke negara tetangga yang notabennya sudah relatif maju.

Adapun dasar hukum dari usaha bela negara di Indonesia terutama terdapat dalam Batang Tubuh UUD NRI 1945 khususnya pada pasal 28J, ayat (1), berbunyi "Setiap orang wajib menghormati hak asasi manusia orang lain dalam tertib kehidupan bermasyarakat, berbangsa dan bernegara". dan 30 ayat (1) yang berbunyi "Tiap-tiap warga negara berhak dan wajib ikut serta dalam usaha pertahanan dan keamanan negara".Sementara itu, dalam ayat (2) disebutkan bahwa "Usaha pertahanan dan keamanan negara dilaksanakan melalui sistem pertahanan dan keamanan rakyat semesta oleh Tentara Nasional Indonesia dan Kepolisisan Negara Republik Indonesia, sebagai 
kekuatan utama, dan rakyat sebagai kekuatan pendukung".

Selanjutnyamengenai bela negara terdapat juga dalam UU No.39/1999, tentang Hak Asasi Manusia, yakni pada pasal 68 yang berbunyi "Setiap warga negara wajib ikut dalam upaya pembelaan negara sesuai dengan ketentuan peraturan perundangundangan" dan UU No.56/1999, pasal 3. Dengan demikian mestinya sudah tidak ada alasan lagi bagi setiap warga negara Indonesia untuk tidak membela negara dari berbagai ancaman yang datang dari luar dan dalam, sesuai dengan profesi masing-masing.

\section{Simpulan}

Setiap warga negara Indonesia wajib ikut serta dalam usaha pembelaan negara mulai dari tingkat desa sampai pada tingkat nasional. Hal ini mengingat dasar hukum yang sudah sangat jelas dilukiskan bahwa pembelaan negara "wajib dilakukan oleh semua warga negara tanpa terkecuali".

Nah, dengan demikian menjadi sangat penting bahwa setiap warga negara Indonesia menyadari apa arti penting usaha pembelaan terhadap negara dalam rangka mempertahankan keutuhan NKRI yang majemuk dengan tetap berpegang teguh pada Pancasila dan UUD NRI 1945 sebagai bingkai yang mempersatukan seluruh elemen negara ini dari Sabang sampai Merauke dengan menesampingkan berbagai bentuk paham primordialisme yang berlebihan.

Setiap pendidik, para orang tua, para pejabat, dan seluruh elemen masyarakat wajib mengetahui dan melaksanakan setiap usaha pembelaan terhadap negara dengan caranya masing-masing. Bagi para pendidik, usaha pembelaan terhadap negara dapat dilakukan dengan cara mengabdikan diri sebagai tenaga pendidik yang benar-benar menunaikan tugas serta tanggung jawabnya dengan sebaik mungkin, yang meliputi tugas mengajar, mendidik dan membimbing para generasi mendatang.

Bagi para prajurit TNI dan pihak kepolisian, usaha pembelaan terhadap negara dapat dilakukan melalui bakti terhadap nusa dan bangsa dengan menjalankan tugas penuh rasa tanggung jawab serta bisa bebas dari berbagai bentuk tindakan yang bisa mengarah pada KKN yang pada akhirnya dapat mengurangi rasa ketidakpercayaan 
masyarakat terhadap loyalitas anggota ataupun aparat keamanan sebagai pelindung, pelayan serta pengayom masyarakat luas.

Bagi para orang tua, hal yang dapat dilakukan dalam usaha pembelaan terhadap negara, diantaranya adalah dengan memberikan pendidikan yang setinggi-tinggi terhadap anak-anaknya sebagai bekal mereka untuk hari yang akan datang, sebab dengan mengenyam pendidikan yang tinggi, diharapkan generasi yang akan datang dapat lebih meningkatkan usaha terhadap pembelaan negara dalam berbagai bidang kehidupan.

Keluarga merupakan tempat yang utama dan pertama bagi setiap manusia untuk memperoleh pendidikan, terutama dari kedua orang tuanya, sebab menjadi orang tua merupakan kodrat alam atau hakikatnya sebagai manusia. Oleh karenanya anak-anak tentu harus dipacu supaya mereka bisa terus belajar (long life education), supaya kelak setelah dewasa, mereka dapat menularkan berbagai ilmu pengetahuan yang telah diperoleh dari generasi sebelumnya, dan begitu seterusnya.

Selanjutnya bagi pemerintah, upaya yang dapat dilakukan dalam rangka pembelaan terhadap negara, diantaranya: membangung masyarakat di segala bidang kehidupan, mulai dari tingkat paling bahwa sampai pada level atas. Rakyat merupakan salah satu unsur dari terbentuknya sebuah negara, dimana pemimpin yang baik harus dapat memberikan pelayanan yang maksimal kepada setiap lapisan masyarakat guna menunjang pembangunan yang berkelanjutan.

Dalam membangun, sudah barang tentu harus menerapkan budaya demokrasi, terutama demokrasi yang berdasarkan pada nilai-nilai Pancasila, dimana penerapan pemerintahan dari rakyat, oleh rakyat, dan untuk rakyat harus mendapat prioritas di atas kepentingan peribadi dan golongan.

\section{Daftar Pustaka}

Arikunto, Suharsimi. 2010. Prosedur Penelitian Suatu Pendekatan Praktik. Jakarta: PT. Rineka Cipta

Darmadi, Hamid, 2010. Dimensi Pendidikan Kewarganegaraan di Perguruan Tinggi. Bandung: Alfabeta

Faisal, Sanapiah. 1989. Format-format Penelitian Sosial. Jakarta: PT. Raja Grafindo Persada 
Ikhsanudin, Dkk. 2012. Penelitian

Survei, Korelasional dan

Kausal Serta Analisis

Data.Www.Google.Com:

20/07/2012.

J, Lexy Moleong. 2010. Metodologi Penelitian Kualitatif. Bandung: PT. Remaja Rosdakarya.

Nawawi, Hadari. 2007. Metode Penelitian Sosial. Yogyakarta: Gadjah Mada University Press.

Pidarta, Made. 2007. Landasan Pendidikan Stimulus Ilmu Pendidikan Bercorak Indonesia. Jakarta: PT. Renika Cipta.

Post, Kapuas. Jum'at, 8 Juni 2012. 9 (Sembilan) Rumusan Penting Untuk Perbatasan Sintang.

Singarimbun, Masri \& Effendi Sofian. 1995. Metode Penelitian
Survai. Jakarta: PT. Pustaka LP3ES.

Sugiyono. 2011. Metode Penelitian Pendidikan, Pendekatan Kuantitatif, Kualitatif \& $R \& D$. Bandung: PT. Alfabeta.

Syaodih, Nana Sukmadinata. 2010. Metode Penelitian Pendidikan. Bandung: PT. Remaja Rosdakarya.

..UU No.20/2003. 2011. Tentang Sistem Pendidikan Nasional Indonesia.

UU No.39/1999. Hak asasi Manusia.

.UU No.56/1999. Rakyat Terlatih.

2009. Undang-undang Dasar Negara Republik Indonesia 1945. Surabaya: CV. Pustaka Agung Harapan. 